\title{
СИНТЕЗ ЛИТИЕВЫХ СОЛЕЙ ТИЕТАНСОДЕРЖАЩИХ 5-БРОМ-2,4-ДИГИДРО-1,2,4-ТРИАЗОЛ-3-ОНОВ
}

\begin{abstract}
Г.А. Розит, Е.Э. Клен
Кафедра фармацевтической химии с курсами аналитической и токсикологической химии, ФГБОУ ВО «Башкирский государственный медицинский университет» Минздрава России,450008, Россия, Уфа, ул. Ленина, 3.

DOI: 10.19163/MedChemRussia2021-2021-496

E-mail: rozit1993@mail.ru

Производные 1,2,4-триазол-3-она находят широкое применение в медицине. Среди них найдены соединения, обладающие высокой антидепрессивной активностью [1]. Кроме того, производные 1,2,4-триазол-3-она проявляют антиагрегационную и гемореологическую активности [2]. Поэтому синтез новых тиетансодержащих производных 1,2,4-триазол-3-онов является актуальным.

В продолжение поиска веществ, обладающих биологической активностью, нами изучены реакции 5-бром-2,4-дигидро-1,2,4-триазол-3-онов, содержащих тиетановый, тиетан-1-оксидный и тиетан-1,1-диоксидный циклы, с гидроксидом лития, в результате которых получены устойчивые соли. Установлено, что при кипячении соединений 1-3 с 1,2-кратным мольным избытком гидроксида лития в этиловом спирте образуются литиевые соли 4-6 с выходами 77-90\%.
\end{abstract}

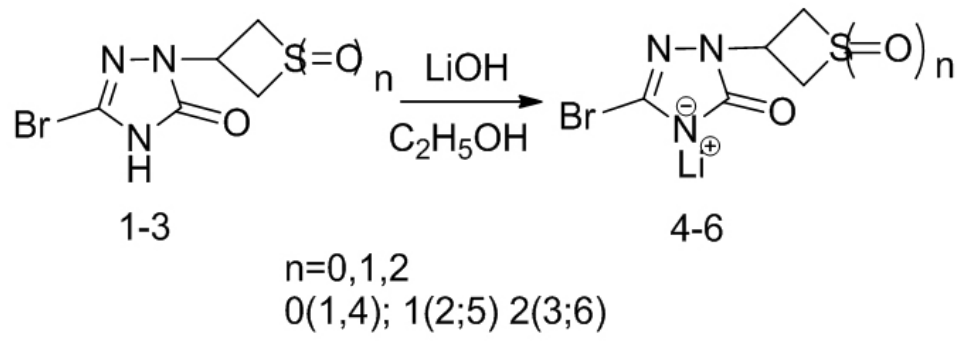

Индивидуальность синтезированных соединений была подтверждена методом TCX, а строение доказано с помощью спектральных методов анализа.

Результаты прогноза биологической активности синтезированных соединений 4-6 в компьютерной программе PASSonline, показали, что соединения 4-6 вероятностью более 0,3 должны являться антагонистами фибриногеновых рецепторов, ингибиторами адгезии тромбоцитов, стимуляторами захвата 5-гидрокситриптамина и др.

\section{Литература}

[1] Е.Э. Клен, И. Л. Никитина; А. Г. Гильманова; А. Ф. Мифтахова; О. А.Иванова; Ф.А. Халиуллин; Е. К. Алехин. Пат.2459818, (2021), № 2011118399/04.

[2] К.Г. Гуревич, А.Л. Ураков, Г.А. Розит, Е.Э. Клен, А.В. Самородов, Ф.А. Халиуллин, Хим.-фарм.журн., (2021), 55 (5). 